Supporting Information for:

\title{
Atom Transfer Radical Polymerization of Acrylic and Methacrylic Acids: Preparation of Acidic Polymers with Various Architectures
}

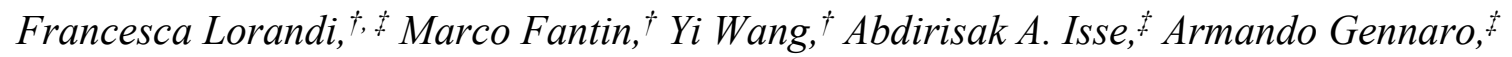

$$
\text { Krzysztof Matyjaszewski } i^{*}
$$

†Department of Chemistry, Carnegie Mellon University, 4400 Fifth Ave, 15213, Pittsburgh, PA.

Department of Chemical Sciences, University of Padova, via Marzolo 1, 35131, Padova, Italy. 


\section{Table of contents}

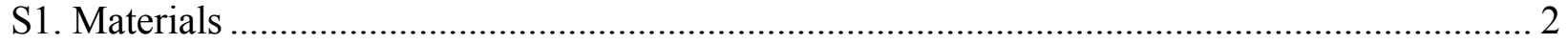

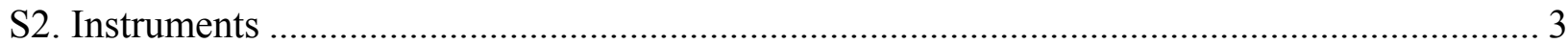

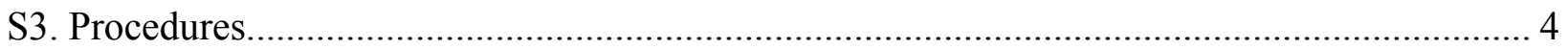

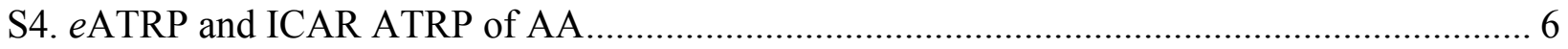

S5. Block copolymers of methacrylic and acrylic acid by eATRP and SARA-ATRP............... 12

\section{S1. Materials}

Acrylic acid (AA, 99\%, Sigma Aldrich) and methacrylic acid (MAA, 99\%, Sigma Aldrich) were both distilled in vacuum through a $10 \mathrm{~cm}$ Vigreux column to remove polymerization inhibitors, and kept in a refrigerator. $\mathrm{CuCl}_{2}\left(99 \%\right.$, Sigma Aldrich), $\mathrm{CuBr}_{2}(99 \%$, Sigma-Aldrich), tris(2pyridylmethyl)amine (TPMA, 98\%, Sigma Aldrich or AmBeed), 2-bromoisobutyric acid (BiBA, 98\%, Sigma Aldrich), $\alpha$-chlorophenylacetic acid (CPAA, 97\%, Sigma Aldrich), 2,2dichloropropionic acid (DCPA, Dalapon, Sigma Aldrich or 95\%, TCI America), trichloroacetic acid (TCAA, $\geq 99 \%$, Sigma Aldrich), $\mathrm{NaCl}$ (Fisher Scientific, 99.0\%), 2,2'-azobis[2-(2-imidazolin2-yl)propane]dihydrochloride (VA-044, Wako Chemicals), and 37\% $\mathrm{HCl}$ aqueous solution (Fisher Scientific, ACS grade) were used as received. Copper wire (Alfa-Aesar, 99.9\%) was washed in $\mathrm{MeOH} / \mathrm{HCl}(3: 1, \mathrm{v} / \mathrm{v})$, then rinsed with methanol and dried under nitrogen.

2-Chloroisobutyric acid (CiBA) was synthesized according to a reported procedure. ${ }^{1}$ In the first step, chlorobutanol emihydrate was synthesized via a nucleophilic addition of chloroform to acetone, catalyzed by $\mathrm{KOH}$. The second step was a variation of the pinacol-pinacolone rearrangement:

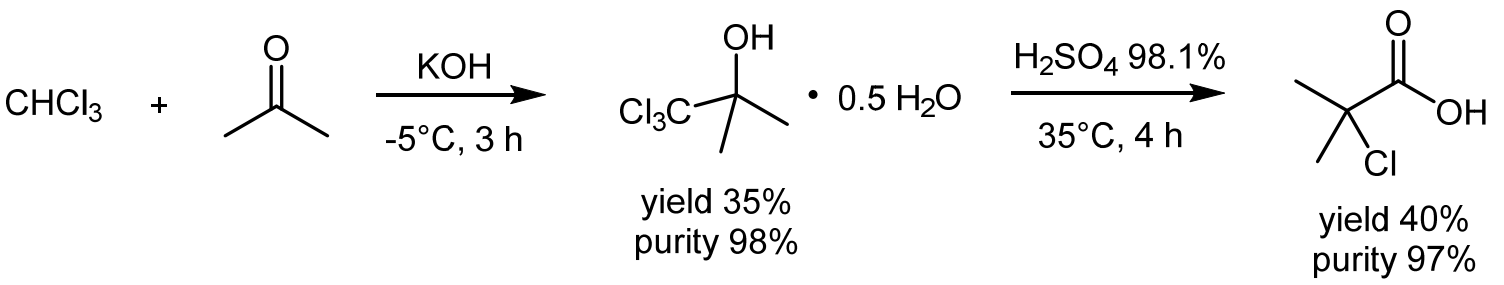

2-Chloroisobutyric acid (CiBA). $125 \mathrm{~mL}$ of acetone, $14 \mathrm{~mL}$ of chloroform and 1 gram of powdered $\mathrm{KOH}$ were mixed in a $250 \mathrm{~mL}$ flask, and the reaction mixture was stirred at $-5^{\circ} \mathrm{C}$ for 3 
hours. The resulting suspension was filtered, and the solvent was evaporated at a rotavap. The yellow oily residue was mixed with $200 \mathrm{~mL}$ of ice-cold water to precipitate chlorobutanol hemihydrate as a white crystalline material. The precipitate was filtered and dried in vacuum for $24 \mathrm{~h} .10 .5 \mathrm{~g}$ of chlorobutanol hemihydrate were added slowly under agitation to $11.2 \mathrm{~mL}$ of $98 \%$ $\mathrm{H}_{2} \mathrm{SO}_{4}$, in a flask placed in a cooling bath. After about $4 \mathrm{~h}$ the evolution of $\mathrm{HCl}$ subsided and the reaction mixture was poured over ca. $20 \mathrm{~g}$ of cracked ice. The organic material was extracted 3 times with cyclohexane, dried over $\mathrm{MgSO}_{4}$ and filtered. Cyclohexane was evaporated and 2chloroisobutyric acid was isolated by distillation (b.p. $60^{\circ} \mathrm{C}, 3.5$ torr). Reported purity were estimated by ${ }^{1} \mathrm{H}$ NMR spectroscopy.

\section{S2. Instruments}

Electrochemical equipment. Electrochemical experiments were conducted on an Autolab PGSTAT100N (Metrohm) or Autolab PGSTAT302N (Metrohm) or Gamry Reference 600, in a 6neck electrochemical cell with a three-electrode setup. For cyclic voltammetry (CV), the working electrode was a glassy carbon (GC) disk (Metrohm or Gamry, $3 \mathrm{~mm}$ diameter); the GC surface was cleaned before each experiment, by polishing with a $0.25 \mu \mathrm{m}$ diamond paste, followed by ultrasonically rinsing in ethanol for 5 minutes. The counter electrode was a Pt ring, whereas the reference electrode was a saturated calomel electrode (SCE). For electrolysis (eATRP), the working electrode was a Pt mesh (geometrical area $\sim 6 \mathrm{~cm}^{2}$, Alfa Aesar) or two, electrically connected Pt meshes (geometrical area $\sim 30 \mathrm{~cm}^{2}$ and surface area to reaction volume ratio of 2 $\mathrm{cm}^{2} / \mathrm{mL}$ ). The Pt meshes were activated in $0.1 \mathrm{M} \mathrm{H}_{2} \mathrm{SO}_{4}$ with cyclic anodic/cathodic steps of 6 seconds with a current density of $\sim 30 \mathrm{~mA} / \mathrm{cm}^{2}$, for a total time of $30 \mathrm{~min}$, otherwise the $\mathrm{Pt}$ electrodes were activated through flame cleaning. The counter electrode was a Pt foil separated from the working solution by using a glass frit filled with a methylcellulose gel and a conductive solution of $\mathrm{Et}_{4} \mathrm{NBF}_{4}$ in DMF.

Gel permeation chromatography (GPC). Polymer molecular weight $\left(M_{\mathrm{n}}\right)$ and dispersity $(\nexists)$ were determined by aqueous GPC, equipped with Agilent PL aquagel-OH columns (guard, 30, 50) at $30^{\circ} \mathrm{C}$, and a refractive index detector set at $35^{\circ} \mathrm{C}$, or a Waters RI detector and PSS columns. A calibration based on PSS poly(sodium methacrylate) standards (in $0.1 \mathrm{M} \mathrm{Na}_{2} \mathrm{HPO}_{4}$ at $30^{\circ} \mathrm{C}$ ) was 
used for both PMAA and PAA samples. Before the analysis, polymer samples were passed through a PES filter.

The use of linear poly(sodium methacrylate) standards introduced uncertainty in the determination of MW values of PAA samples and of star-shaped PMAA and PAA, due to the different hydrodynamic volume of different polymers and architectures. However, better agreement between theoretical and measured MW was observed when using more active (i.e. more efficient) initiators. While the latter gave PMAA with MW values close to theoretical ones $(<15 \%$ difference), MW values of PAA were systematically $\sim 30-40 \%$ higher than estimated by the adopted calibration standards.

Nuclear magnetic resonance (NMR). Monomer conversion was measured by NMR spectroscopy, conducted on a Bruker Avance III spectrometer operating at $500 \mathrm{MHz}$ for ${ }^{1} \mathrm{H}$, in $\mathrm{D}_{2} \mathrm{O}$ as solvent.

\section{S3. Procedures}

Typical procedure of $\boldsymbol{e A T R P}$ of acrylic acid. A 6-neck electrochemical cell was equipped with the three electrodes described above and kept at $T=25^{\circ} \mathrm{C}$ by using a thermostat. The cell was charged with $29.3 \mathrm{mg}$ of $\mathrm{NaCl}(0.5 \mathrm{mmol}), 1.5 \mathrm{~mL}$ of AA (21.9 mmol), $14.6 \mathrm{mg}$ of TPMA (0.050 $\mathrm{mmol}), 0.252 \mathrm{~mL}$ of a $0.05 \mathrm{M} \mathrm{CuCl}_{2}$ stock solution $(0.012 \mathrm{mmol} \mathrm{Cu}), 0.013 \mathrm{~mL}$ of DCPA $(0.126$ mmol) and $13.2 \mathrm{~mL}$ of $\mathrm{H}_{2} \mathrm{O}$. CVs were recorded before and after DCPA addition, in order to i) measure the standard reduction potential of the $\mathrm{Cu}$ catalyst, ii) observe the catalytic effect upon the introduction of the initiator. The working solution was bubbled with $\mathrm{N}_{2}$ for $30 \mathrm{~min}$. Then, the electrodes were connected to the potentiostat and the selected potential value was applied $\left(E_{\mathrm{app}}\right)$. During electrolysis, the cathodic compartment was maintained under vigorous magnetic stirring.

Typical procedure of ICAR ATRP of acrylic acid. $19.3 \mathrm{mg}$ of $\mathrm{NaCl}(0.33 \mathrm{mmol}), 2.5 \mathrm{~mL}$ of AA (36.5 mmol), $9.75 \mathrm{mg}$ of TPMA (0.034 mmol), $0.168 \mathrm{~mL}$ of a $0.05 \mathrm{M} \mathrm{CuCl}_{2}$ stock solution $(0.008 \mathrm{mmol} \mathrm{Cu}), 0.0086 \mathrm{~mL}$ of DCPA $(0.084 \mathrm{mmol})$, and $8.15 \mathrm{mg}$ VA-044 $(0.025 \mathrm{mmol})$ were added to $7.33 \mathrm{~mL}$ of $\mathrm{H}_{2} \mathrm{O}$. The solution was degassed for at least $30 \mathrm{~min}$ at room temperature, then the flask was placed in an oil bath heated at $45^{\circ} \mathrm{C}$. 
Typical procedure of $\boldsymbol{e A T R P}$ of methacrylic acid. The electrochemical cell was prepared as previously described. Then, $0.20 \mathrm{~g}$ of $\mathrm{NaCl}(3.42 \mathrm{mmol}), 2.0 \mathrm{~mL}$ of MAA (23.6 mmol), $14.6 \mathrm{mg}$ of TPMA ( $0.050 \mathrm{mmol}), 0.236 \mathrm{~mL}$ of a $0.05 \mathrm{M} \mathrm{CuCl}_{2}$ stock solution $(0.012 \mathrm{mmol} \mathrm{Cu}), 1.18 \mathrm{~mL}$ of a $0.10 \mathrm{M} \mathrm{CiBA}$ solution $(0.118 \mathrm{mmol}), 2.1 \mathrm{~mL}$ of a $1.2 \mathrm{M} \mathrm{HCl}$ solution $(2.52 \mathrm{mmol} \mathrm{HCl})$ and $14.5 \mathrm{~mL}$ of $\mathrm{H}_{2} \mathrm{O}$ were added. $\mathrm{CV}$ were recorded before and after $\mathrm{CiBA}$ addition, in order to i) measure the standard reduction potential of the $\mathrm{Cu}$ catalyst, ii) observe the catalytic effect upon the introduction of the initiator. The working solution was bubbled with $\mathrm{N}_{2}$ for $30 \mathrm{~min}$. Then, the electrodes were connected to the potentiostat and the selected potential value was applied ( $\left.E_{\text {app }}\right)$. During electrolysis, the cathodic compartment was maintained under vigorous magnetic stirring.

Typical procedure of SARA ATRP of methacrylic acid. $0.050 \mathrm{~g}$ of $\mathrm{NaCl}(0.86 \mathrm{mmol}), 0.5 \mathrm{~mL}$ of MAA ( $0.508 \mathrm{~g}, 5.9 \mathrm{mmol}), 2.6 \mathrm{mg}$ of TPMA $(0.009 \mathrm{mmol}), 0.051 \mathrm{~mL}$ of a $0.05 \mathrm{M} \mathrm{CuCl}_{2}$ stock solution $(0.0026 \mathrm{mmol} \mathrm{Cu}), 0.295 \mathrm{~mL}$ of a $0.100 \mathrm{M}$ BiBA solution $(0.0295 \mathrm{mmol})$, and $0.525 \mathrm{~mL}$ of a $1.2 \mathrm{M} \mathrm{HCl}$ solution $(0.63 \mathrm{mmol})$ were added to $3.75 \mathrm{~mL}$ of $\mathrm{H}_{2} \mathrm{O}$. The solution was degassed for at least $30 \mathrm{~min}$ and then transferred to a previously degassed and sealed flask containing a 10 $\mathrm{cm} \mathrm{Cu}$ wire with diameter $d=1 \mathrm{~mm}$. The copper wire was previously activated with $\mathrm{MeOH} /$ aqueous $\mathrm{HCl}(3: 1, \mathrm{v} / \mathrm{v})$, rinsed with $\mathrm{MeOH}$ and dried under $\mathrm{N}_{2}$.

Typical procedure of PMAA-Cl macroinitiator synthesis via eATRP. A 6-neck electrochemical cell equipped with three electrodes and thermostated at $T=25{ }^{\circ} \mathrm{C}$ was charged with $0.26 \mathrm{~g}$ of $\mathrm{NaCl}(4.4 \mathrm{mmol}), 3.75 \mathrm{~mL}$ of MAA ( $44.3 \mathrm{mmol}), 20.6 \mathrm{mg}$ of TPMA (0.071 mmol), $0.36 \mathrm{~mL}$ of a $0.05 \mathrm{M} \mathrm{CuCl}_{2}$ stock solution $(0.018 \mathrm{mmol} \mathrm{Cu}), 0.091 \mathrm{~mL}$ of DCPA $(0.88 \mathrm{mmol}$, degree of polymerization $(\mathrm{DP})=50), 1.6 \mathrm{~mL}$ of a $1.25 \mathrm{M} \mathrm{HCl}$ solution $(2.0 \mathrm{mmol} \mathrm{HCl})$ and 9.2 $\mathrm{mL}$ of $\mathrm{H}_{2} \mathrm{O}$. The working solution was bubbled with $\mathrm{N}_{2}$ for $30 \mathrm{~min}$. Then, the electrodes were connected to the potentiostat and the selected potential value was applied ( $\left.E_{\text {app }}\right)$. During electrolysis, the cathodic compartment was maintained under vigorous magnetic stirring. The reaction was stopped after reaching $\sim 40 \%$ MAA conversion within $2 \mathrm{~h}$. The polymerization solution was poured into $100 \mathrm{~mL}$ of diethyl ether to precipitate the macroinitiator. The polymer was re-dissolved in ethanol and re-precipitated in $100 \mathrm{~mL}$ diethyl ether. The procedure was repeated 3 times. The final polymer was dried in a vacuum oven for $24 \mathrm{~h}$.

Chain extension of PMAA-Cl macroinitiator via SARA ATRP. $24.1 \mathrm{~g}$ of $\mathrm{NaCl}(0.41 \mathrm{mmol})$, $0.5 \mathrm{~mL}$ of MAA (5.6 mmol), $3.4 \mathrm{mg}$ TPMA (0.012 mmol), $0.006 \mathrm{~mL}$ of a $0.05 \mathrm{M} \mathrm{CuCl}_{2}$ stock 
solution $(0.0026 \mathrm{mmol} \mathrm{Cu})$, and $0.52 \mathrm{~mL}$ of a $1.2 \mathrm{M} \mathrm{HCl}$ solution $(0.65 \mathrm{mmol})$ were added to 3.9 $\mathrm{mL}$ of $\mathrm{H}_{2} \mathrm{O}$. The solution was degassed for at least $30 \mathrm{~min}$ and then transferred to a previously degassed and sealed flask containing a $10 \mathrm{~cm} \mathrm{Cu}$ wire with diameter $d=1 \mathrm{~mm}$ and $55 \mathrm{mg}$ of purified PMAA-Cl macroinitiator $(0.029 \mathrm{mmol}, \mathrm{DP}=200)$. The macroinitiator was not solubilized with other components to prevent hydrolysis of the chain ends. The copper wire was previously activated with $\mathrm{MeOH} /$ aqueous $\mathrm{HCl}(3: 1, \mathrm{v} / \mathrm{v})$, rinsed with $\mathrm{MeOH}$ and dried under $\mathrm{N}_{2}$.

Chain extension of PMMA-Cl macroinitiator via eATRP. A 6-neck electrochemical cell equipped with three electrodes and thermostated at $T=25{ }^{\circ} \mathrm{C}$ was charged with $52.6 \mathrm{mg}$ of $\mathrm{NaCl}$ (0.9 mmol), $0.6 \mathrm{~mL}$ of AA ( $8.74 \mathrm{mmol}), 10.1 \mathrm{mg}$ of TPMA ( $0.035 \mathrm{mmol}), 0.175 \mathrm{~mL}$ of a $0.05 \mathrm{M}$ $\mathrm{CuCl}_{2}$ stock solution $(0.009 \mathrm{mmol} \mathrm{Cu})$ and $11.2 \mathrm{~mL}$ of $\mathrm{H}_{2} \mathrm{O}$. The working solution was bubbled with $\mathrm{N}_{2}$ for $30 \mathrm{~min} .165 \mathrm{mg}$ of PMMA-Cl macroinitiator $(0.044 \mathrm{mmol}, \mathrm{DP}=200)$ were added to the degassed solution just before applying the selected potential value ( $\left.E_{\text {app }}\right)$.

\section{S4. eATRP and ICAR ATRP of AA}

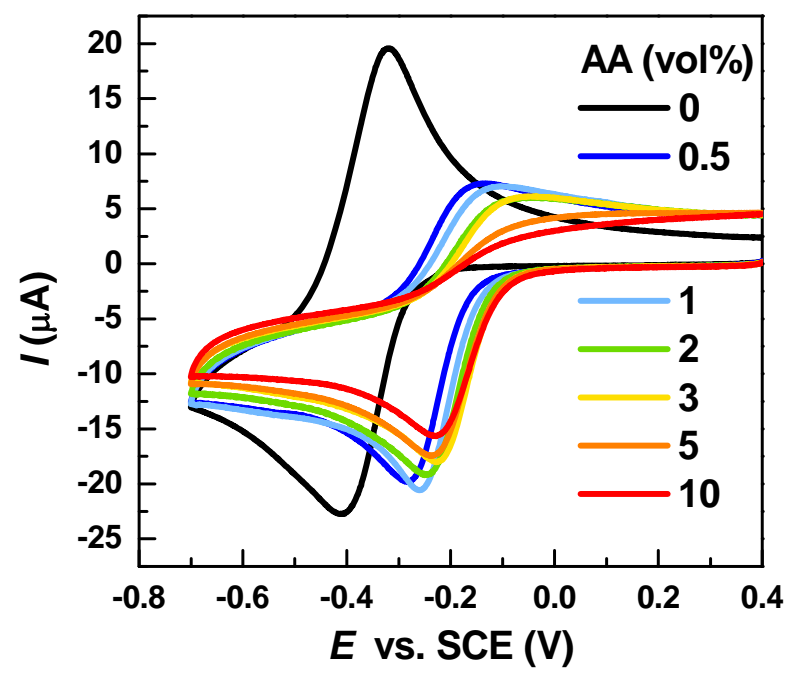

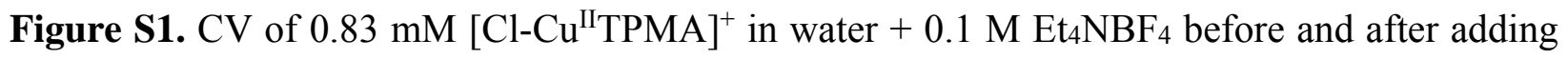
increasing amounts of acrylic acid. $C_{\mathrm{Cu}^{\mathrm{II}}(\mathrm{OTf})_{2}} / C_{\mathrm{TPMA}} / C_{\mathrm{Cl}^{-}}=0.1 / 0.11 / 2$, recorded on a $\mathrm{GC}$ disk, at a scan rate of $0.2 \mathrm{~V} \mathrm{~s}^{-1}, T=25^{\circ} \mathrm{C}$. 
In Figure S1, the reduction potential of the complex moves to more positive values with increasing the amount of AA monomer, which is typically observed for ATRP catalysts. ${ }^{2}$ This results in decreased activity of the complex in monomer/solvent mixtures rather than in pure solvent and is ascribed to the different polarity of the media. In addition, the current intensity of the reduction peak decreases, likely because of a decrease in the diffusion coefficient of the $\mathrm{Cu}$ complex with increasing the concentration of the monomer, according to the Randles-Sevcik equation. ${ }^{3}$

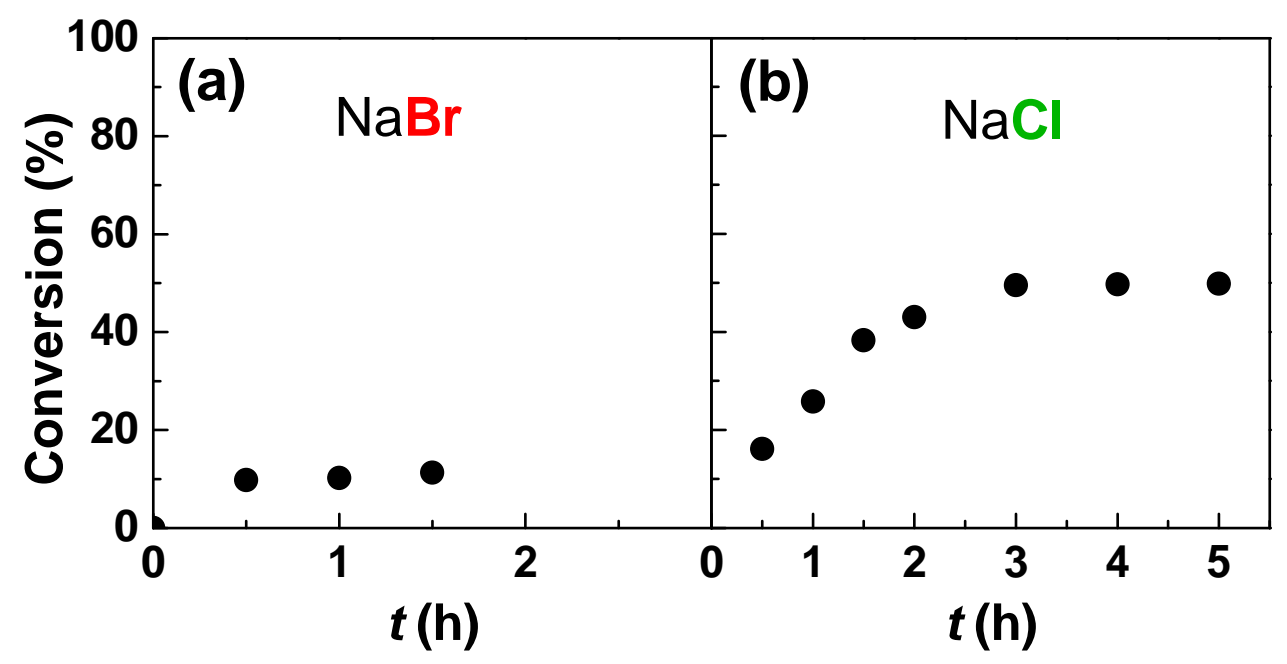

Figure S2. Monomer conversion over time in $e$ ATRP of AA 10 vol $\%$ in $\mathrm{H}_{2} \mathrm{O}, T=25^{\circ} \mathrm{C}, \mathrm{pH}=2$, $C_{\mathrm{AA}} / C_{\mathrm{HEBBi}} / C_{\mathrm{Cu}{ }^{\mathrm{II}} \mathrm{X}_{2}} / \mathrm{C}_{\mathrm{TPMA}} / C_{\mathrm{X}^{-}}=175 / 1 / 0.1 / 0.4 / 4, C_{\mathrm{AA}}=1.46 \mathrm{M}, E_{\text {app }}=-0.3 \mathrm{~V}$ vs. SCE, (a) X= Br, (b) $\mathrm{X}=\mathrm{Cl}$.

Table S1. $e$ ATRP of 10 vol\% AA in Figure S2.

\begin{tabular}{lllllll}
\hline Entry & $\mathrm{X}$ & $t(\mathrm{~h})$ & Conv. $(\%)$ & $M_{\mathrm{n}, \mathrm{th}} \times 10^{-3}$ & $M_{\mathrm{n}} \times 10^{-3 \mathrm{a}}$ & $\Xi$ \\
\hline 1 & $\mathrm{Br}$ & $0.5^{\mathrm{b}}$ & 11 & 1.6 & 4.2 & 2.56 \\
2 & $\mathrm{Cl}$ & $3^{\mathrm{b}}$ & 50 & 6.4 & 13.8 & 1.83
\end{tabular}

${ }^{a}$ Measured by GPC (eluent: $0.1 \mathrm{M} \mathrm{Na}_{2} \mathrm{HPO}_{4}$ in $\mathrm{H}_{2} \mathrm{O}$; calibration: poly(sodium methacrylate) standards). ${ }^{\mathrm{b}}$ The conversion did not significantly change in the following hours. 
Table S2. Effect of the solution pH on eATRP of 10 vol\% AA in water at $25{ }^{\circ} \mathrm{C} .^{\mathrm{a}}$

\begin{tabular}{lllllllll}
\hline Entry & $\mathrm{pH}$ & $\begin{array}{l}E_{\text {app vs SCE }} \\
(\mathrm{V})\end{array}$ & $\begin{array}{l}t \\
(\mathrm{~h})\end{array}$ & $\begin{array}{l}\text { Conv. } \\
(\%)\end{array}$ & $\begin{array}{l}k_{\mathrm{p}}^{\mathrm{app}} \\
\left(\mathrm{h}^{-1}\right)\end{array}$ & $M_{\mathrm{n}, \mathrm{th}} \times 10^{-3}$ & $M_{\mathrm{n}} \times 10^{-3 \mathrm{~b}}$ & $Ð$ \\
\hline 1 & 2 & -0.30 & 5 & 54 & 0.17 & 6.9 & 12.8 & 1.76 \\
2 & 1.4 & -0.26 & 5 & 27 & 0.06 & 3.5 & 9.2 & 1.76 \\
3 & 0.9 & -0.245 & 5 & 11 & - & 1.5 & 3.5 & 2.03
\end{tabular}

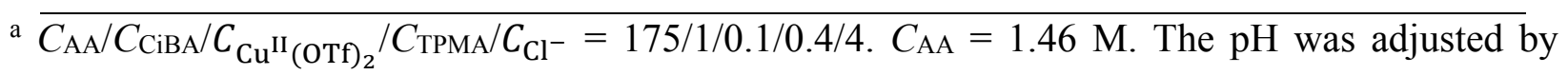
addition of $\mathrm{HCl} .{ }^{\mathrm{b}}$ Measured by GPC (eluent: $0.1 \mathrm{M} \mathrm{Na}_{2} \mathrm{HPO}_{4}$ in $\mathrm{H}_{2} \mathrm{O}$; calibration: poly(sodium methacrylate) standards).

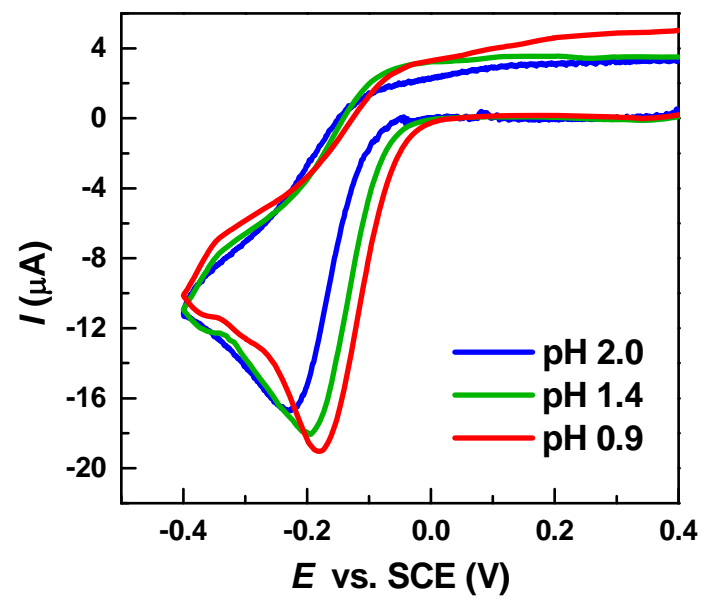

Figure S3. $\mathrm{CV}$ of $0.83 \mathrm{mM}\left[\mathrm{Cl}-\mathrm{Cu}^{\mathrm{II}} \mathrm{TPMA}\right]^{+}$in $\mathrm{AA} 10 \mathrm{vol} \%$ in $\mathrm{H}_{2} \mathrm{O}+0.1 \mathrm{M} \mathrm{Et}_{4} \mathrm{NBF}_{4}$ before (blue) and after addition of different amounts of $\mathrm{HCl}$ (green and red). $C_{\mathrm{Cu}^{\mathrm{II}}(\mathrm{OTf})_{2}} / C_{\mathrm{TPMA}} / C_{\mathrm{Cl}^{-}}=$ $0.1 / 0.4 / 4$, recorded on a GC disk at a scan rate of $0.2 \mathrm{~V} \mathrm{~s}^{-1}, T=25^{\circ} \mathrm{C}$. 

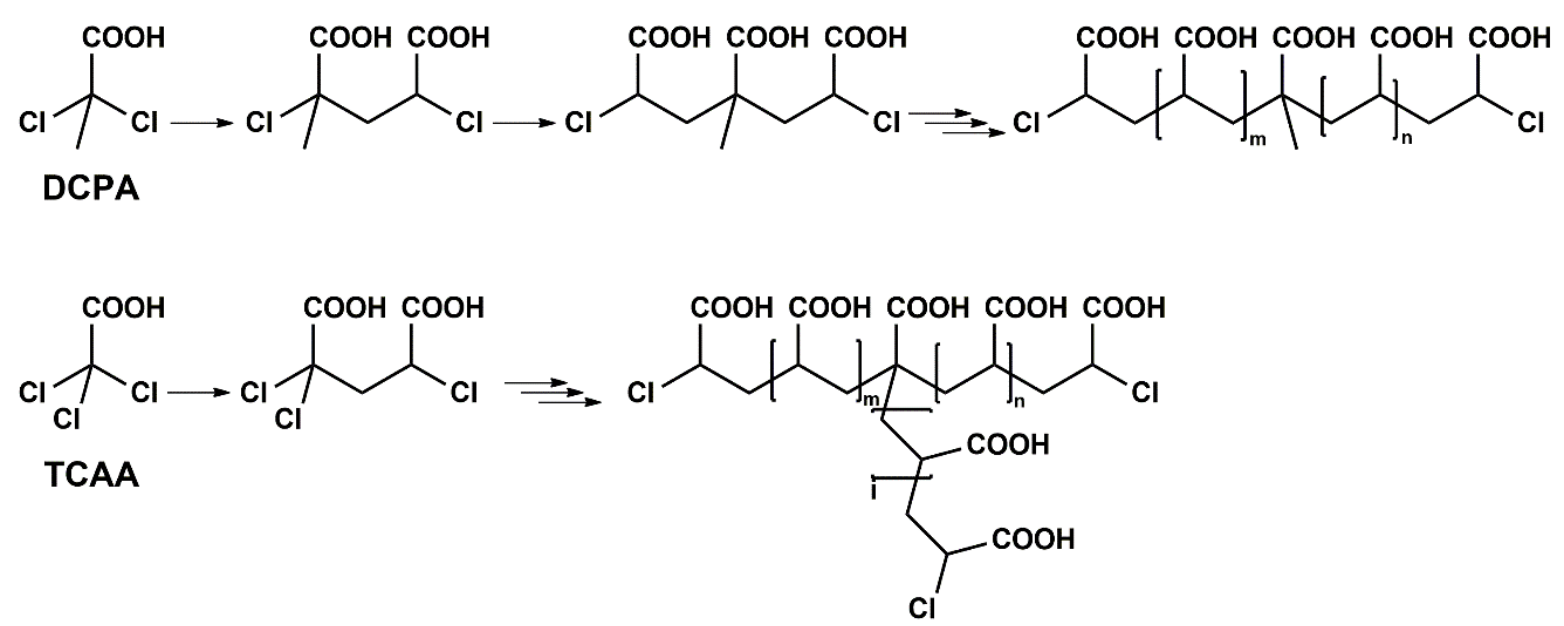

Scheme S1. General scheme for the formation of (top) telechelic PAA using the bifunctional initiator DCPA, and (bottom) three-arm star shaped PAA using the trifunctional initiator TCAA.

DCPA generated 2 chains per initiator molecule, resulting, therefore, in telechelic polymers (Scheme S1, top): the symmetry of dormant species ensured the chain growth from both sides. TCAA generated 3 chains per molecule (Scheme S1, bottom), as supported by: i) the higher activation of the remaining $\mathrm{C}-\mathrm{Cl}$ after activation of the first two $\mathrm{C}-\mathrm{Cl}$ bonds, because of the penultimate effect; ${ }^{4}$ ii) the increase in $k_{\text {p,app }}$ with the number of $\mathrm{Cl}$ atoms in the initiator: both DCPA and TCAA behave as if the concentration of active halogen atoms was twice or three times higher, respectively, than in the case of CiBA. Analogous structures are expected for ATRP of MAA initiated by DCPA and TCAA (Table 2 and Figure 2 in the main text). The initiation of all $3 \mathrm{C}-\mathrm{Cl}$ bonds in the case of MAA was further proved by performing a SARA ATRP of $10 \mathrm{vol} \%$ MAA in $\mathrm{D}_{2} \mathrm{O}$, with target $\mathrm{DP}=20\left(C_{\mathrm{MAA}} / C_{\mathrm{TCAA}} / C_{\mathrm{Cu}^{\mathrm{II}} \mathrm{Cl}_{2}} / C_{\mathrm{TPMA}} / C_{\mathrm{Cl}^{-}}=20: 1: 0.001: 0.03: 5\right.$, total $V$ $=5 \mathrm{~mL}, 10 \mathrm{~cm} \mathrm{Cu}$ wire with diameter $d=1 \mathrm{~mm}$ ). The polymerization was allowed to proceed for $2 \mathrm{~h}$, a long enough time to observe termination of all chains. ${ }^{13} \mathrm{C}$ NMR of the polymerization mixture (Figure S4) did not show any peak in the typical range of C-Cl bonds (55-70 ppm). 


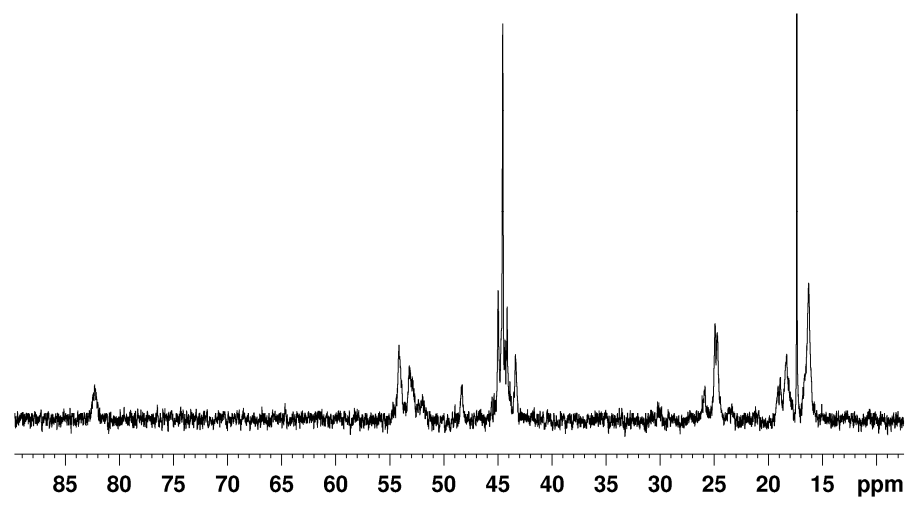

Figure S4. ${ }^{13} \mathrm{C}$ NMR of the polymerization mixture after $2 \mathrm{~h}$ of SARA ATRP of 10 vol\% MAA in $\mathrm{D}_{2} \mathrm{O}$, with target $\mathrm{DP}=20\left(C_{\mathrm{MAA}} / C_{\mathrm{TCAA}} / C_{\mathrm{Cu}^{\mathrm{II}} \mathrm{Cl}_{2}} / C_{\mathrm{TPMA}} / C_{\mathrm{Cl}^{-}}=20: 1: 0.001: 0.03: 5\right.$, total $V=5$ $\mathrm{mL}, 10 \mathrm{~cm} \mathrm{Cu}$ wire with diameter $d=1 \mathrm{~mm})$.
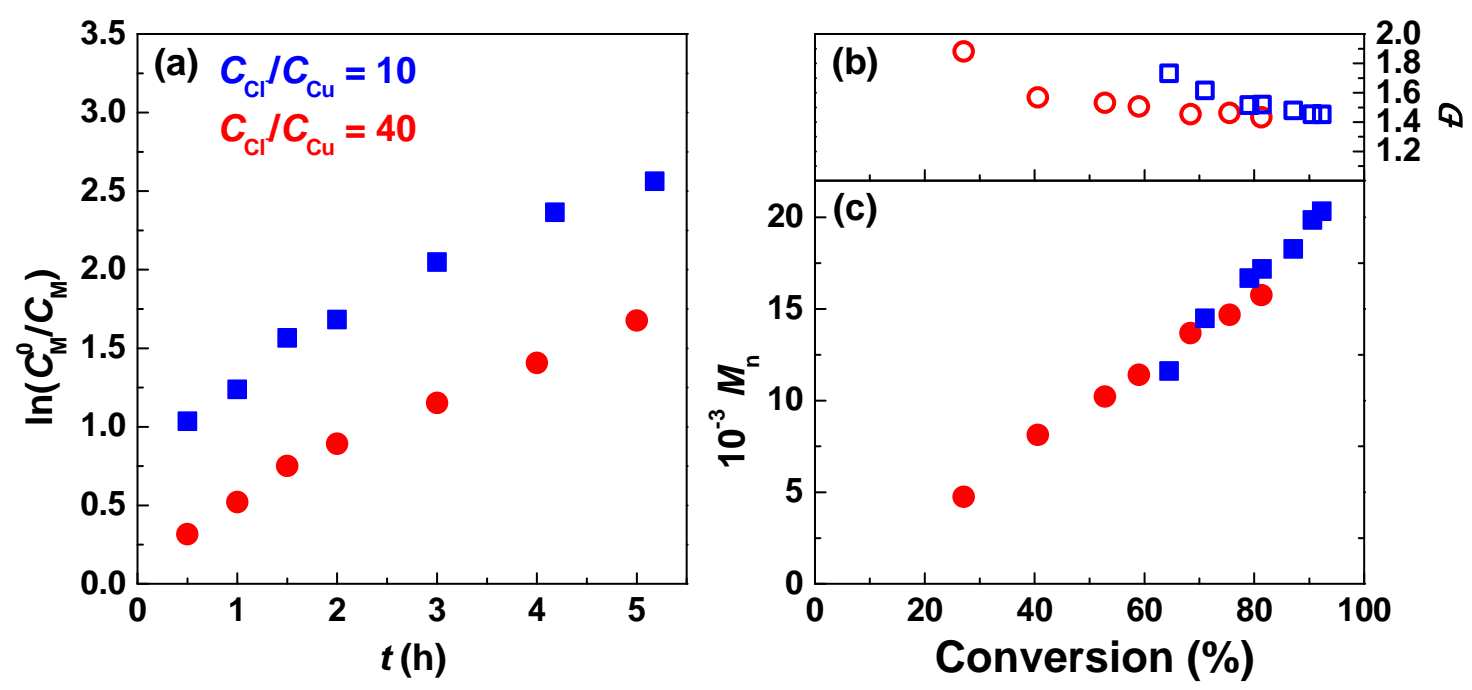

Figure S5. $e$ ATRP of $10 \mathrm{vol} \%$ AA in water by varying $C_{\mathrm{Cl}^{-}}=0.033 \mathrm{M}$ (red), $0.008 \mathrm{M}$ (blue); kinetic plots (a) and evolution of dispersity (b) and MWs (c) with conversion. Polymerization conditions: $C_{\mathrm{AA}} / C_{\mathrm{DCPA}} / C_{\mathrm{Cu}^{\mathrm{II}} \mathrm{Cl}_{2}} / C_{\mathrm{TPMA}}=175 / 1 / 0.1 / 0.4, C_{\mathrm{Cu}^{\mathrm{II}} \mathrm{Cl}_{2}}=0.8 \times 10^{-3} \mathrm{M}, \mathrm{pH}=2, T=25^{\circ} \mathrm{C}$. 

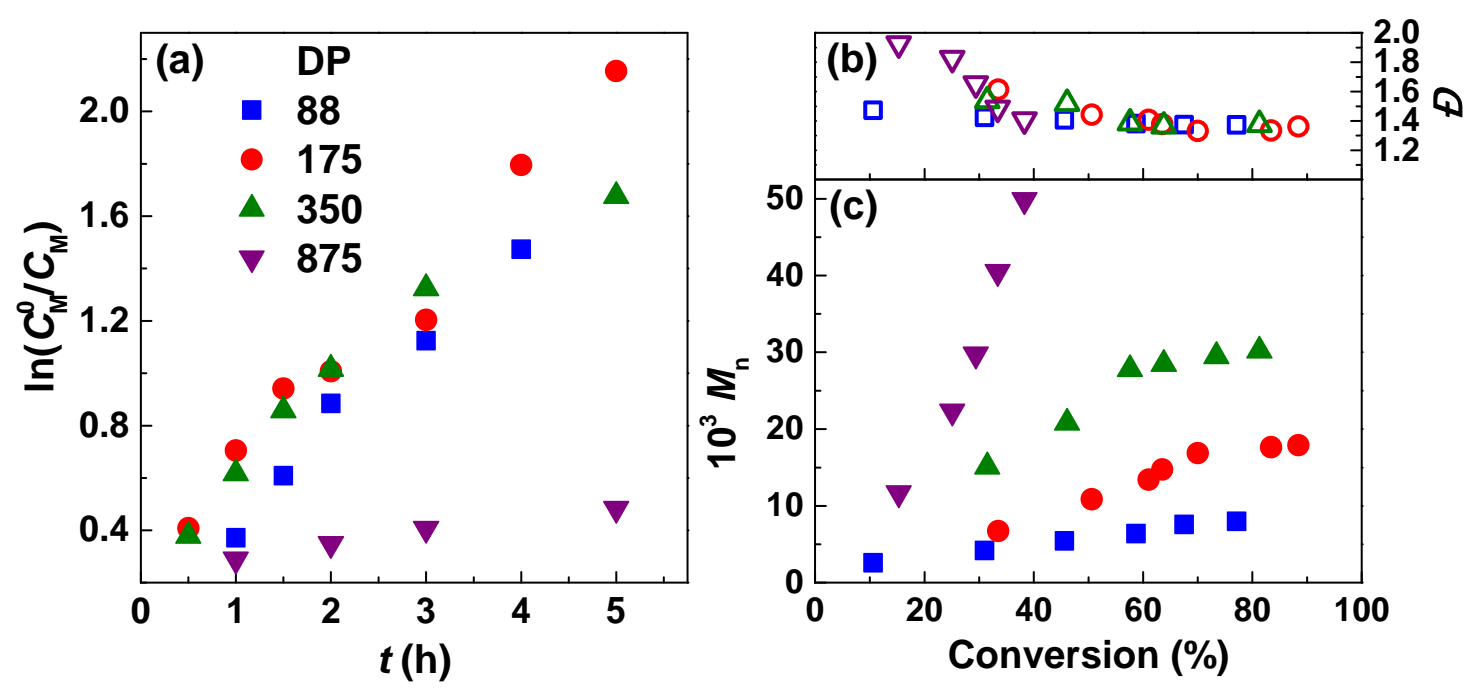

Figure S6. $e$ ATRP of AA in water by varying monomer loading $(5,10,20,50$ vol\%, corresponding to $\mathrm{DP}=88,175,350$, and 875 , respectively), kinetic plots (a) and evolution of dispersity (b) and MWs (c) with conversion. Polymerization conditions: $C_{\mathrm{TCAA}} / C_{\mathrm{Cu}^{\mathrm{II}} \mathrm{Cl}_{2}} / C_{\mathrm{TPMA}} / C_{\mathrm{Cl}^{-}}=1 / 0.1 / 0.4 / 4$, $C_{\mathrm{Cu}^{\mathrm{II}} \mathrm{Cl}_{2}}=0.8 \times 10^{-3} \mathrm{M}, T=25^{\circ} \mathrm{C}$.

Table S3. $e A T R P$ of AA in water with varying $\mathrm{Cu}$ loading, at $\mathrm{pH}=2$. $^{\mathrm{a}}$

\begin{tabular}{|c|c|c|c|c|c|c|c|c|}
\hline Entry & $C_{\mathrm{DCPA}} / C_{\mathrm{Cu}}$ & $\begin{array}{l}E_{\text {app }} \quad \text { vs. } \\
\text { SCE (V) }\end{array}$ & $\begin{array}{l}t \\
\text { (h) }\end{array}$ & $\begin{array}{l}\text { Conv. } \\
(\%)\end{array}$ & $\begin{array}{l}k_{\mathrm{p}, \mathrm{app}} \\
\left(\mathrm{h}^{-1}\right)\end{array}$ & $M_{\mathrm{n}, \mathrm{th}} \times 10^{-3}$ & $M_{\mathrm{n}} \times 10^{-3 \mathrm{~b}}$ & 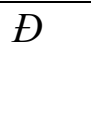 \\
\hline 1 & $1 / 0.2$ & -0.3 & 5 & 74 & 0.32 & 9.4 & 16.3 & 1.46 \\
\hline $2^{c}$ & $1 / 0.1$ & -0.3 & 5 & 81 & 0.37 & 10.3 & 15.8 & 1.43 \\
\hline 3 & $1 / 0.05$ & -0.3 & 5 & 89 & 0.50 & 11.2 & 19.1 & 1.47 \\
\hline 4 & $1 / 0.025$ & -0.3 & 5 & 85 & 0.46 & 10.8 & 18.0 & 1.58 \\
\hline
\end{tabular}


Table S4. ICAR ATRP of AA in water with varying target $\mathrm{DP}$ and $\mathrm{Cu}$ loading, at $\mathrm{pH}=2$. $^{\mathrm{a}}$

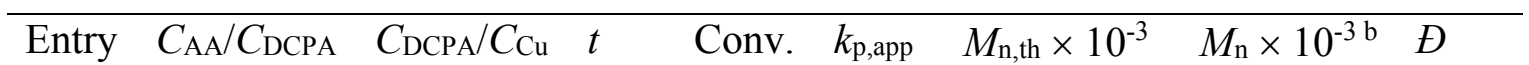

(h) $\quad(\%) \quad\left(h^{-1}\right)$

\begin{tabular}{lllllllll}
\hline 1 & 88 & $1 / 0.05$ & 3.5 & 60 & 0.33 & 3.9 & 2.9 & 1.34 \\
2 & 175 & $1 / 0.05$ & 3.5 & 33 & 0.15 & 4.3 & 4.0 & 1.34 \\
3 & 434 & $1 / 0.05$ & 8 & 54 & 0.12 & 17.0 & 19.7 & 1.47 \\
4 & 434 & $1 / 0.1$ & 16 & 29 & 0.03 & 9.2 & 24.5 & 1.72 \\
5 & 434 & $1 / 0.025$ & 8 & 65 & 0.28 & 20.6 & 25.0 & 1.52
\end{tabular}

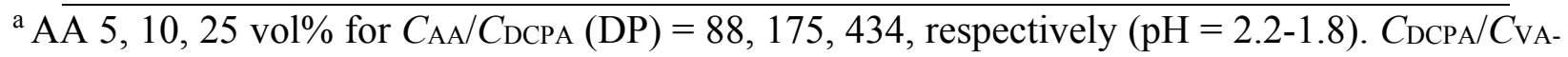
$044=1 / 0.3, C_{\mathrm{DCPA}}=8.4 \times 10^{-3} \mathrm{M} ; C_{\mathrm{Cu}^{\mathrm{II}} \mathrm{Cl}_{2}} / C_{\mathrm{TPMA}} / C_{\mathrm{Cl}^{-}}=1 / 4 / 40, T=45^{\circ} \mathrm{C}, V_{\mathrm{TOT}}=10 \mathrm{~mL} .{ }^{\mathrm{b}}$ Measured by GPC (eluent: $0.1 \mathrm{M} \mathrm{Na}_{2} \mathrm{HPO}_{4}$ in $\mathrm{H}_{2} \mathrm{O}$; calibration: poly(sodium methacrylate) standards).

\section{S5. Block copolymers of methacrylic and acrylic acid by $e$ ATRP and SARA-ATRP}

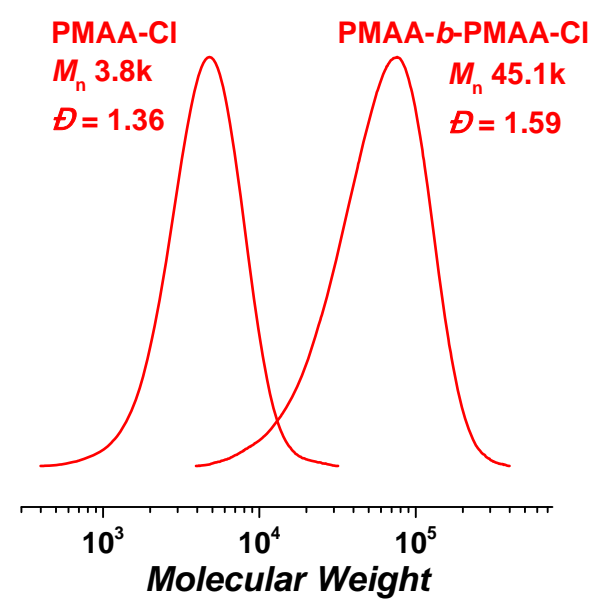

Figure S7. GPC traces of PMAA-Cl macroinitiator and chain extension with MAA. Conditions for the macroinitiator: $e$ ATRP of MAA $25 \mathrm{vol} \%$ in $\mathrm{H}_{2} \mathrm{O}, \mathrm{pH}=0.9, E_{\text {app }}=-0.18 \mathrm{~V}$ vs. $\mathrm{SCE}, V=15$ mL. $C_{\mathrm{MAA}} / C_{\mathrm{DCPA}} / C_{\mathrm{Cu}^{\mathrm{II}} \mathrm{Cl}_{2}} / C_{\mathrm{TPMA}} / C_{\mathrm{Cl}^{-}}=50 / 1 / 0.02 / 0.08 / 5$. Conversion $50 \%$, in $2 \mathrm{~h}$. Conditions for chain extension: SARA-ATRP of 10 vol $\%$ MAA in $\mathrm{H}_{2} \mathrm{O}, \mathrm{pH}=0.9, C_{\mathrm{MAA}} / C_{\text {PMAA- }}$ ${ }_{\mathrm{Cl}} / C_{\mathrm{Cu}^{\mathrm{II}} \mathrm{Cl}_{2}} / C_{\mathrm{TPMA}} / C_{\mathrm{Cl}^{-}}=420 / 1 / 0.02 / 0.8 / 28, \mathrm{Cu}$ wire $2 \times 10 \mathrm{~cm}$, dia. $1 \mathrm{~mm}, V=5 \mathrm{~mL}$. Conversion $84 \%$, in $4.5 \mathrm{~h}$. The GPC traces were recorded using $0.1 \mathrm{M} \mathrm{Na}_{2} \mathrm{HPO}_{4}$ in $\mathrm{H}_{2} \mathrm{O}$ as eluent and poly(sodium methacrylate) standards for calibration. 


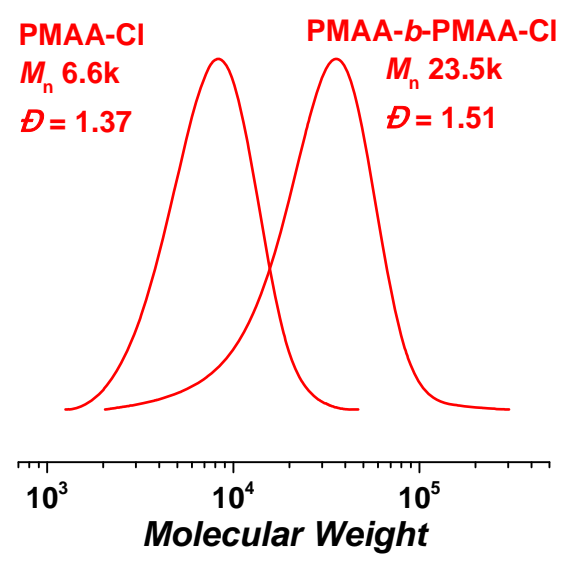

Figure S8. GPC traces of PMAA-Cl macroinitiator and chain extension with MAA via $e$ ATRP. Conditions for the macroinitiator: MAA $25 \mathrm{vol} \%$ in $\mathrm{H}_{2} \mathrm{O}, \mathrm{pH}=0.9, E_{\text {app }}=-0.18 \mathrm{~V}$ vs SCE, $C_{\mathrm{MAA}} / C_{\mathrm{DCPA}} / C_{\mathrm{Cu}^{\mathrm{II}} \mathrm{Cl}_{2}} / C_{\mathrm{TPMA}} / C_{\mathrm{Cl}^{-}}=100 / 1 / 0.05 / 0.1 / 4.3, V=30 \mathrm{~mL}$. Conversion $60 \%$, in $1 \mathrm{~h}$. Conditions for chain extension: MAA 13 vol\% in $\mathrm{H}_{2} \mathrm{O}, \mathrm{pH}=0.9, E_{\text {app }}=-0.18 \mathrm{~V}$ vs $\mathrm{SCE}$, $C_{\mathrm{MAA}} / C_{\mathrm{PMAA}-\mathrm{Cl}} / C_{\mathrm{Cu}^{\mathrm{II}} \mathrm{Cl}_{2}} / C_{\mathrm{TPMA}} / C_{\mathrm{Cl}^{-}}=350 / 1 / 0.1 / 0.4 / 29, V=15 \mathrm{~mL}$. Conversion $76 \%$, in $3 \mathrm{~h}$. The GPC traces were recorded using $0.1 \mathrm{M} \mathrm{Na}_{2} \mathrm{HPO}_{4}$ in $\mathrm{H}_{2} \mathrm{O}$ as eluent and poly(sodium methacrylate) standards for calibration.

Table S5. eATRP of MAA and chain extension of PMAA-CI with MAA or AA by SARA ATRP or ATRP. $^{a}$

\begin{tabular}{|c|c|c|c|c|c|c|c|c|c|}
\hline Entry & Technique & $\begin{array}{l}\text { Target } \\
\text { DP }\end{array}$ & $\begin{array}{l}E_{\text {app }} \text { vs. } \\
\text { SCE (V) }\end{array}$ & $\begin{array}{l}t \\
\text { (h) }\end{array}$ & $\begin{array}{l}\text { Conv. } \\
(\%)\end{array}$ & $\begin{array}{l}k_{\mathrm{p}, \mathrm{app}} \\
\left(\mathrm{h}^{-1}\right)\end{array}$ & $\begin{array}{l}M_{\mathrm{n}, \mathrm{th}} \\
\times 10^{-3}\end{array}$ & $\begin{array}{l}M_{\mathrm{n}} \\
\times 10^{-3 \mathrm{~b}}\end{array}$ & $Ð$ \\
\hline $\begin{array}{l}\text { PMAA-CI (Figure } \\
3 \text { main text and Figure } \\
\text { S7) }\end{array}$ & $e$ ATRP & 50 & -0.18 & 2 & 50 & 0.33 & 2.3 & 3.8 & 1.36 \\
\hline $\begin{array}{l}\text { PMAA-b-PMAA } \\
\text { (Figure } 3 \text { main text) }\end{array}$ & SARA & 200 & - & 2 & 93 & 1.41 & 19.7 & 23.9 & 1.41 \\
\hline $\begin{array}{l}\text { PMAA-b-PMAA } \\
\text { (Figure S7) }\end{array}$ & SARA & 420 & - & 4.5 & 84 & 0.45 & 34.1 & 45.1 & 1.59 \\
\hline $\begin{array}{l}\text { PMAA-b-PAA } \\
\text { (Figure } 3 \text { main text) }\end{array}$ & $e$ ATRP & 200 & -0.3 & 1.5 & 40 & 0.41 & 9.5 & 9.5 & 1.42 \\
\hline $\begin{array}{l}\text { PMAA-Cl } \\
\text { (Figure S8) }\end{array}$ & $e$ ATRP & 100 & -0.18 & 1 & 59 & 0.89 & 5.2 & 6.6 & 1.37 \\
\hline $\begin{array}{l}\text { PMAA-b-PMAA } \\
\text { (Figure S8) }\end{array}$ & $e$ ATRP & 350 & -0.18 & 3 & 76 & 0.44 & 23.8 & 23.5 & 1.51 \\
\hline
\end{tabular}




\section{References}

1. Kundiger, D. G.; Ikenberry, E. A.; Ovist, E.; Peterson, J. G.; Dick, C. R. The Rearrangement of Certain Trichloromethylcarbinols to $\alpha$-Chloro Acid Chloridesla. J. Am. Chem. Soc. 1960, 82, 2953-2956. 2. Isse, A. A.; Lorandi, F.; Gennaro, A. Electrochemical approaches for better understanding of atom transfer radical polymerization. Curr. Opin. Electrochem. 2019, 15, 50-57.

3. Bard, A. J.; Faulkner, L. R.; Leddy, J.; Zoski, C. G., Electrochemical methods: fundamentals and applications. wiley New York: 1980; Vol. 2.

4. Lin, C. Y.; Coote, M. L.; Petit, A.; Richard, P.; Poli, R.; Matyjaszewski, K. Ab initio study of the penultimate effect for the ATRP activation step using propylene, methyl acrylate, and methyl methacrylate monomers. Macromolecules 2007, 40, 5985-5994. 